Jurnal Agro Vol. IV, No. 2, 2017

\title{
PENAMPILAN AGRONOMIS DAN PENDUGAAN PARAMETER GENETIK 100 GALUR PADI GENERASI LANJUT PADA KONDISI CEKAMAN KEKERINGAN
}

\section{AGRONOMICAL PERFORMANCE AND GENETIC PARAMETER ESTIMATION OF 100 RICE ADVANCE LINES ON DROUGHT STRESS CONDITION}

\author{
Wage Ratna Rohaeni dan Untung Susanto \\ Balai Besar Penelitian Padi, Jl. 9 Sukamandi-Subang. Kode pos: 41256 \\ Korespondensi : wagebbpadi@gmail.com
}

Diterima 25 Agutus 2017 / Disetujui 27 Desember 2017

\begin{abstract}
ABSTRAK
Kondisi sawah tanpa ada pengairan merupakan salah satu masalah di lahan tadah hujan. Lahan sawah seperti ini hanya mengandalkan keberadaan air dari air hujan. Hal tersebut membuat keberadaan air menjadi faktor pembatas pertumbuhan. Penelitian ini bertujuan untuk mengetahui penampilan galur-galur generasi lanjut, mengetahui nilai duga parameter genetik serta memperoleh galur terbaik pada kondisi kekeringan. Sebanyak 100 galur untuk toleransi kekeringan generasi lanjut (>F8) diujicobakan dengan menggunakan rancangan Augmanted design dengan lima blok. Sebanyak enam varietas pembanding diikutsertakan pada percobaan. Penelitian dilakukan pada MK 2015 di Kebun Percobaan BB Padi-Sukamandi. Hasil penelitian menunjukkan bahwa pada kondisi kekeringan menghasilkan keragaan nilai rata-rata galur untuk karakter tinggi tanaman $103,44 \mathrm{~cm}$, jumlah anakan produktif 12 anakan, persentase pengisian bulir bernas hanya mencapai $60,46 \%$, indeks warna daun 39,37 , bobot 1.000 butir rata-rata sekitar $26,34 \mathrm{~g}$ dengan bobot hasil gabah per 5 rumpun $166,34 \mathrm{~g}$. Karakter hasil pada kondisi kekeringan apabila dikonversikan ke hektar adalah sebesar 3,77 t ha- ${ }^{-1}$. Hampir semua karakter memiliki variabilitas yang luas, nilai heritabilitas tinggi dan \% KGH yang tinggi kecuali jumlah bulir bernas per malai. Galur BP17572C-SBY-1-CRB-2-SKI-1-3-PWK-2, ZX115-SKI-0-IND-2-SKI-1-PWK-2， BP30104e， BP17572c-SBY-1-CRB-2-SKI-1-4-PWK-2, dan BP17554-1C-SBY-1-CRB-8-SKI-1-6-PWK-2 memberikan keragaan terbaik dengan potensi hasil lebih tinggi daripada pembanding terbaik yaitu Inpari 13. Terdapat sepuluh galur harapan untuk dilanjutkan pada uji daya hasil pendahuluan untuk perakitan varietas padi tadah hujan.
\end{abstract}

Kata kunci: galur generasi lanjut, kekeringan, keragaan, padi, parameter genetik

\begin{abstract}
The condition of rice field without any irrigation is one of the problems in the rainfed land. This rice field only relies on the existence of water during the rainy day. This causes the limitation of water availability which affect plant growth. This study aimed to know the performance of the rice advance lines, estimated the value of genetic parameters and obtains the best line on drought condition. As many as 100 advance lines (> F8) for drought tolerant were tested using Augmented Design in five blocks. A total of six-check varieties were included in the experiment. The research was conducted at Dry Season of 2015 in ICRR-Sukamandi
\end{abstract}


Experimental Field. The result showed that on the drought condition gained the average value for plant height as $103,44 \mathrm{~cm}$, number of productive tillers as 12 tillers, percentage of filling pine grains reached $60,46 \%$, leaf color index as 39,37 , and weight of 1.000 grains averaged as $26,34 \mathrm{~g}$, while weight grain per 5 clumps as $166,34 \mathrm{~g}$. Yield trait was converted to hectares as $3,77 \mathrm{t} \mathrm{ha}^{-1}$ in drought conidition. Almost all characters had wide variability, high heritability values and high percentage of expected genetic advance except the number of filling grains per panicle trait. Lines BP17572C-SBY-1-CRB-2-SKI-1-3-PWK-2, ZX115-SKI-0-IND-2-SKI-1-PWK-2, BP30104e, BP17572c-SBY-1-CRB-2 -SKI-1-4-PWK-2, and BP17554-1c-SBY-1-CRB-8-SKI-1-6-PWK2 provided the best performance with higher yield potential than the best check i.e. Inpari 13. There are ten promising lines which can be continued to the preliminary test for the assembly of rainfed rice varieties.

Key words : advance lines, drought, genetic parameter, performance, rice

\section{PENDAHULUAN}

Irigasi terbatas masih menjadi salah satu kendala utama dalam budidaya padi di Indonesia. Sistem irigasi terbatas merupakan sistem irigasi yang ada di lahan sawah tadah hujan, dimana irigasi hanya terbatas pada keberadaan air hujan. Data menunjukkan sebanyak $26,5 \%$ dari lahan basah di Indonesia adalah lahan sawah tadah hujan (Wahyunto, 2009). Artinya, seluas kurang lebih 3,4 juta hektar sawah di Indonesia rawan kekeringan (Basis Data Deptan, 2017). Pada sawah tadah hujan, air hanya tersedia ketika musim hujan sehingga tanaman akan rawan terkena cekaman kekeringan pada saat musim kemarau. Beberapa teknologi penunjang budidaya tadah hujan sudah banyak, namun teknologi varietas unggul baru adaptif kondisi sawah tadah hujan masih menjadi andalan teknologi bagi petani karena dapat mengurangi biaya yang dikeluarkan untuk pengairan.

Produktivitas padi pada lahan irigasi terbatas jauh lebih rendah dibandingkan sawah dengan irigasi teknis. Produksi padi pada sistem walik jerami yang diaplikasikan pada budidaya sawah tadah hujan dengan irigasi murni dari keberadaan air hujan memberikan hasil rata-rata $<3 \mathrm{t} \mathrm{ha}^{-1}$ (Syamsiah et al., 1994). Produksi padi sawah tadah hujan dengan sistem budidaya di Jawa Tengah menghasilkan nilai rata-rata produksi 3,0-3,5 t ha ${ }^{-1}$ (Fagi, 1995). Sedangkan produktivitas padi pada sistem irigasi sumur pantek/penyedotan air pada lahan tadah hujan mencapai rata-rata 6,77 $\mathrm{t}$ ha ${ }^{-1}$ untuk VUB Inpari 10 (Rohaeni et al., 2015).

Pengembangan galur-galur padi adaptif pada lahan tadah hujan dengan pengairan terbatas masih terus dikembangkan guna meringankan biaya produksi. Penggunaan varietas oleh petani tadah hujan masih didominasi oleh varietas-varietas lokal seperti Cibogo, Cigeulis, dan Way Apo Buru (Prihasto, 2013). Varietas unggul baru yang telah dilepas dan adaptif lahan tadah hujan atau toleran terhadap kekeringan diantaranya Inpari 10 dan 19 (BB Padi, 2015). Tambahan VUB terbaru diantaranya Inpari 38, 39, 40 dan 41. Aplikasi sistem pengelolaan tanaman terpadu, VUB pada budidaya gogorancah lahan tadah hujan mampu memberikan hasil panen setara pada sawah irigasi (Pane et al., 2009). Dengan demikian pengembangan galurgalur adaptif irigasi terbatas harus terus 
dilakukan karena menjadi harapan bagi petani.

Penelitian ini bertujuan untuk mengetahui keragaan galur-galur generasi lanjut, mengetahui nilai duga parameter genetik serta memperoleh galur terbaik pada kondisi kekeringan.

\section{BAHAN DAN METODE}

Penelitian dilaksanakan pada Musim Kering tahun 2015 di Kebun Percobaan BB Padi Sukamandi, Kelompok Peneliti Pemuliaan dan Plasma Nutfah, Balai Besar Tanaman Padi. Sebanyak 100 galur generasi lanjut yang berasal dari 58 persilangan turunan tetua toleran kekeringan hasil seleksi tadah hujan (pedigree disajikan pada Tabel 1) digunakan pada percobaan set kekeringan dengan menggunakan rancangan Augmented Design lima blok dan enam Cek.

Tabel 1. Pedigree materi genetik

\begin{tabular}{cl}
\hline No & Pedigree Materi Genetik \\
\hline 1 & N22/2AS996-9/3*Inpari13 \\
2 & IRGC 100641 [TWC 40-5] / IRGC \\
& 100847 [O. SATIVA/O NIVARA] \\
3 & IR 83142-B-60-B/Inpari 10 \\
4 & IR89848/INPARI 13 \\
5 & IR89856/CIHERANG \\
6 & IR89860/INPARI 13 \\
7 & Sansari/Inpari 13//Inpari 13 \\
8 & Niew Tew/Ciherang//Ciherang \\
9 & TNAU 6484/Inpari 13//Inpari 13 \\
10 & IRGC 100847 [O. sativa/O. nivara]/ \\
& Inpari 13//Inpari13 \\
11 & HHZ9/INPARI 13 \\
12 & IR89860/INPARI 13 \\
13 & Mutasi GSR \\
14 & Hanareumbyeo/Dular \\
15 & Gayabyeo/Dular \\
16 & IR89860/INPARI 13
\end{tabular}

\begin{tabular}{|c|c|}
\hline No & Pedigree Materi Genetik \\
\hline 17 & $\begin{array}{l}\text { IRGC } 101398 \\
{[\text { O.NIVARA/O.SATIVA]/Ciherang }}\end{array}$ \\
\hline 18 & IRGC 101969 [W1744]/Inpari13 \\
\hline 19 & IRGC 104436 [G.S.6075] / Ciherang \\
\hline 20 & IRGC 102475 [W18]/Inpari13 \\
\hline 21 & IRGC 101969 [W1744]/Inpari13 \\
\hline 22 & $\begin{array}{l}\text { IRGC } 100847 \text { [O. sativa/O. nivara] / } \\
\text { Inpari 13//Ciherang }\end{array}$ \\
\hline 23 & $\begin{array}{l}\text { Ciherang/IRGC } 104846 \text { [G.S. } \\
\text { 10551]//Ciherang }\end{array}$ \\
\hline 24 & IRGC 101969 [W1744]/Inpari14 \\
\hline 25 & IRGC 101969 [W1744]/Inpari15 \\
\hline 26 & IRGC 101983 [W1770]/Ciherang \\
\hline 27 & IRGC 100191 [W0594]/Inpari13 \\
\hline 28 & IRGC 100191 [W0594]/Inpari14 \\
\hline 29 & $\begin{array}{l}\text { Ciherang/IRGC } 104846 \text { [G.S. } \\
\text { 10551]//Ciherang }\end{array}$ \\
\hline 30 & IRGC 100191 [W0594]/Inpari15 \\
\hline 31 & IRGC 101969 [W1744]/Ciherang \\
\hline 32 & IRGC 100191 [W0594]/Inpari13 \\
\hline 33 & IRGC 100191 [W0594]/Inpari14 \\
\hline 34 & IR66/Dular//Inpari 13///Inpari 10 \\
\hline 35 & N22/2*AS996-9/2*Ciherang \\
\hline 36 & Gayabyeo/Dular//Inpari 13///Inpari 10 \\
\hline 37 & Gayabyeo/Dular//Inpari 13///Inpari 11 \\
\hline 38 & $\begin{array}{l}\text { Dular } / 2^{*} \mathrm{NSIC} \\
\text { Rc } 160 / 2^{*} \text { Ciherang/Bahbutong }\end{array}$ \\
\hline 39 & $\begin{array}{l}\text { Jinmibyeo/Nipponbare } / 3^{*} \text { Ciherang/Wan } \\
\text { xian } 78\end{array}$ \\
\hline 40 & $\begin{array}{l}\text { N22/2*Gayabyeo/3*Ciherang/////Bahbut } \\
\text { ong }\end{array}$ \\
\hline 41 & $\begin{array}{l}\text { N22/2*Junambyeo/2*Ciherang////Lalan// } \\
\text { ///Batutegi }\end{array}$ \\
\hline 42 & IRGC104429(G.S 6069)/Ciherang \\
\hline 43 & Blok Runti/ Inpari 18 \\
\hline 44 & $\begin{array}{l}\text { N22/2*Junambyeo } / / 2^{*} \text { Ciherang/5/Lalan/ } \\
\text { 6/Batutegi/7/Barumun }\end{array}$ \\
\hline 45 & Situ Bagendit/IR 83140-B-11-B \\
\hline 46 & HHZ5/INPARI 13 \\
\hline 47 & IR89848/INPARI 13 \\
\hline 48 & IR89856/CIHERANG \\
\hline 49 & IR89856/INPARI 13 \\
\hline 50 & IR 77390-37-B-17-2-B-B-B \\
\hline 51 & Ciherang/WTR1//Ciherang/Zhonghua 1 \\
\hline 52 & Ciherang/ZX 117//Ciherang \\
\hline 53 & Ciherang/Wanxian $77 / /$ Ciherang \\
\hline
\end{tabular}




\begin{tabular}{cl}
\hline No & Pedigree Materi Genetik \\
\hline 54 & $\begin{array}{l}\text { Ciherang/Huanghuazhan//Ciherang/Zh } \\
\text { onghua 1 }\end{array}$ \\
55 & Ciherang/ZX 117//Ciherang/WTR1 \\
56 & Ciherang/Zhongzu 14 \\
57 & Ciherang/ZX 117 \\
58 & Ciherang/WTR1 \\
\hline
\end{tabular}

Pelaksanaan percobaan dilakukan dengan mengkondisikan pertanaman pada musim kering. Pengolahan lahan dilakukan sebanyak 1 kali pengolahan tanah. Ploting dilakukan dengan luas tanam per nomor galur $1 \times 5$ m dengan jarak tanam $20 \times 20$ $\mathrm{cm}$. Pengairan diberikan 1 kali yaitu pada saat olah tanah. Lahan dibiarkan tanpa pemberian air irigasi setelah umur 1 bulan setelah tanam sampai dengan panen. Pemupukan dilakukan sebanyak 2 kali dengan total dosis pupuk phonska $300 \mathrm{~kg}$ $\mathrm{ha}^{-1}$ dan urea maksimal $80 \mathrm{~kg} \mathrm{ha}^{-1}$.

Sistem pengendalian air agar tidak ada rembesan air dari areal sekitar dilakukan dengan pemasangan lapisan plastik pada pematang sekeliling areal. Indikator kedalaman air tanah dipasang untuk mengetahui posisi ketinggian air dalam tanah. Pengukuran kandungan air dilakukan 3 kali (vegetatif, awal fase generatif dan pada saat panen). Kondisi tanah diupayakan pada kondisi kekeringan (tanah sawah retak-retak) dengan tidak memberikan suplai air irigasi ke plot percobaan dengan rata-rata tinggi muka air tanah $>30 \mathrm{~cm}$ dibawah permukaan tanah.

Pengamatan dilakukan pada pengukuran karakter agronomis diantaranya: bobot brangkasan rumpun saat panen, bobot brangkasan rumpun setelah dikeringkan (oven), tinggi tanaman, jumlah malai sehat per rumpun, jumlah gabah isi/malai, jumlah gabah hampa/malai, bobot gabah total/malai, bobot 1000 butir, bobot gabah per rumpun (hasil). Analisis data dilakukan dengan menggunakan software SAS system versi 6 dengan menggunakan protokol analisis varian untuk rancangan Augmented Design (Tabel 2).

Tabel 2. Sidik Ragam Augmented Design (Federer \& Ragavaro, 1975; Petersen, 1994)

\begin{tabular}{lccc}
\hline \multicolumn{1}{c}{ Sumber Keragaman } & Derajat bebas & Kuadrat tengah & $\mathrm{E}(\mathrm{KT})^{*}$ \\
\hline Total & $\mathrm{rc}+\mathrm{g}$ & & \\
Faktor koreksi & 1 & & \\
Blok & $\mathrm{r}-1$ & & \\
Perlakuan & $(\mathrm{g}+\mathrm{c})-1$ & & \\
$\quad$ Cek & $\mathrm{c}-1$ & $\mathrm{KTc}$ & $\sigma^{2} \mathrm{e}+\mathrm{r}^{2} \mathrm{c}$ \\
$\quad$ Genotipe Uji & $\mathrm{g}-1$ & $\mathrm{KTg}$ & $\sigma^{2} \mathrm{e}+\sigma^{2} \mathrm{~g}$ \\
$\quad$ Cek vs Genotipe Uji & 1 & & \\
Galat & $((\mathrm{g}+\mathrm{rk})-1)-((\mathrm{g}+\mathrm{k})-1)$ & $\mathrm{KTe}$ & $\sigma^{2} \mathrm{e}$ \\
Residu & $(\mathrm{r}-1)(\mathrm{c}-1)$ & & \\
\hline
\end{tabular}

Keterangan: * sumber PTTIPB (2008)

Pendugaan nilai heritabilitas arti luas berdasarkan penurunan rumus sidik ragam:

$$
\begin{aligned}
& \sigma^{2}{ }_{\varepsilon}=\mathrm{KTe} / \mathrm{r} \\
& \sigma^{2}{ }_{G}=\mathrm{KTg}-\mathrm{KTe} \\
& \sigma^{2}{ }_{P}=\sigma^{2} \mathrm{G}+\sigma^{2} \varepsilon \\
& \mathrm{h}^{2} \mathrm{bs}=\sigma_{\mathrm{G}}^{2} / \sigma^{2}{ }_{\mathrm{P}}
\end{aligned}
$$

Keterangan:

$\sigma_{\varepsilon}^{2}=$ ragam lingkungan

$\sigma_{G}^{2}=$ ragam genotipik

$\sigma^{2}{ }_{p}=$ ragam fenotipik

$\mathrm{h}^{2}{ }_{\mathrm{bs}}=$ heritabilitas arti luas (broad sense) 
Kriteria nilai heritabilitas arti luas menurut Stanfield (1991):

Rendah : $h^{2}$ bs $<0,2$

Sedang : $0.2<h^{2} b s \leq 0,5$

Tinggi $: h^{2} b s>0,5$

Pendugaan variabilitas genetik dan fenotipik karakter:

$$
\begin{aligned}
& \sigma_{\sigma^{2} G}=\sqrt{\frac{2}{r^{2}}\left\{\frac{M S_{g}^{2}}{d b_{g}+2}+\frac{M S_{e}{ }^{2}}{d b_{e}+2}\right\}} \\
& \sigma_{\sigma^{2} r}=\sqrt{\frac{2}{r^{2}}\left\{\frac{M S_{g}^{2}}{d b_{g}+2}\right\}}
\end{aligned}
$$

Keragaman genetik dikatakan luas apabila $\sigma_{G}^{2} \geq 2 \sigma_{\sigma_{G}^{2}}$ dan dikatakan sempit apabila $\sigma_{G}^{2}<2 \sigma_{\sigma_{G}^{2}}$. Keragaman fenotipik dikatakan luas apabila $\sigma_{P}^{2} \geq 2 \sigma_{\sigma_{P}^{2}}$ dan dikatakan sempit apabila $\sigma_{\mathrm{P}}^{2}<2 \sigma_{\sigma_{P}^{2}}$.

Pendugaan kemajuan genetik (Falconer, 1989):

$$
\mathrm{KGH}=\mathrm{i} \times \mathrm{h}^{2} \times \sigma_{\mathrm{P}} ; \% \mathrm{KGH}=\mathrm{KGH} / \mu \times 100 \%
$$

Keterangan:

$\mathrm{KGH}=$ kemajuan genetik harapan yang diperoleh berdasarkan dengan pemakaian metode seleksi tertentu (i.e kondisi cekaman kekeringan)
I = intensitas seleksi pada tingkat $10 \%$

$h^{2} \quad$ (sebesar 1,76)

$\mathrm{h}^{2}=$ Heritabilitas

$\sigma_{\mathrm{p}}=$ simpangan baku fenotipik

$\mu \quad=$ rataan umum

Kriteria persentase kemajuan genetik harapan yaitu: rendah $=0<\mathrm{KGH}<3,3 \%$; agak rendah $=3,3 \%<\mathrm{KGH}<6,6 \%$; cukup tinggi $=6,6 \%<\mathrm{KGH}<10 \%$; tinggi $=\mathrm{KGH}>$ $10 \%$.

\section{HASIL DAN PEMBAHASAN}

\section{Penampilan Karakter Agronomi 100 Galur}

Analisa sidik ragam menunjukkan tidak semua karakter agronomi pada galur-galur berbeda nyata. Perbedaan nyata antar galur pada taraf $5 \%$ terdapat pada karakter tinggi tanaman, umur berbunga, bobot brangkasan kering, bobot 1.000 butir dan karakter hasil. Sedangkan pengujian perbandingan antara galur dengan 5 cek (live_vs_check) menunjukkan perbedaan yang nyata hampir pada semua karakter kecuali karakter bobot basah dan kering brangkasan serta persentase jumlah bulir isi per malai (seed set) (Tabel 3).

Tabel 3. Nilai rata-rata karakter agronomi 100 galur pada kondisi kekeringan

\begin{tabular}{clrrrr}
\hline \multirow{2}{*}{ No } & \multicolumn{1}{c}{ Karakter } & Nilai & Min & Range & StDev \\
\hline 1 & Tinggi tanaman (cm) & 103,44 & 77,0 & 123,3 & 8,4 \\
2 & Jumlah anakan produktif & 12,32 & 6,0 & 20,2 & 2,9 \\
3 & Umur berbunga (HSS) & 66,5 & 59,0 & 79,0 & 4,0 \\
4 & Indeks warna daun (IWD) & 39,37 & 26,4 & 44,2 & 2,7 \\
5 & Bobot brangkasan kering & 33,98 & 22,0 & 56,0 & 24,7 \\
& (g) & & & & \\
6 & Gabah isi & 83,42 & 1,0 & 138,0 & 6,8 \\
7 & Gabah hampa & 54,07 & 20,0 & 108,0 & 20,0 \\
8 & Seed set (\%) & 60,46 & 1,4 & 76,2 & 15,9 \\
9 & Bobot 1.000 butir (g) & 27,34 & 22,4 & 31,5 & 10,1 \\
10 & Hasil (bobot gabah per 5 & 147,49 & 0,0 & 268,0 & 1,8 \\
& rumpun (g)) & & & & \\
\hline
\end{tabular}


Pada kondisi kekeringan, keragaan tinggi tanaman rata-rata dari 100 galur adalah 103,44 cm dengan jumlah anakan produktif 12 anakan. Kondisi kekeringan di lapang memberikan efek stres terutama pada karakter gabah hampa yang hampir $50 \%$ dibandingkan gabah isi. Persentase pengisian bulir bernas hanya mencapai $60,46 \%$. Indeks warna daun rata-rata dari 100 galur adalah 39,37. Bobot 1.000 butir rata-rata sekitar $26,34 \mathrm{~g}$ dengan bobot hasil gabah per 5 rumpun sekitar 166,34 g. Karakter hasil pada kondisi kekeringan apabila dikonversikan ke hektar adalah sebesar $3,77 \mathrm{t} \mathrm{ha}^{-1}$. Nilai ini merupakan nilai rata-rata dari 100 galur yang diujikan. Dengan melihat pendugaan ragam genetik pada 100 galur yang diujikan pada kondisi kekeringan, maka terdapat peluang memperoleh galur-galur yang melebihi nilai hasil rata-rata dari 3,77 t ha ${ }^{-1}$ (Tabel 3).

Tabel 4. Analisis varian karakter agronomi

\begin{tabular}{|c|c|c|c|c|c|}
\hline Sumber Keragaman & F Value & $\operatorname{Pr}>\mathrm{F}$ & Sumber Keragaman & F Value & $\operatorname{Pr}>\mathrm{F}$ \\
\hline Tinggi Tanaman & & & Jumlah Gabah Isi & & \\
\hline Genotipe uji & $20,65^{* *}$ & $<, 0001$ & $\begin{array}{l}\text { Genotipe uji } \\
\text { Genotipe }\end{array}$ & $7,6 * *$ & 0,0012 \\
\hline Genotipe uji_vs_kontrol & $19,55 * *$ & 0,0004 & uji_vs_kontrol & $13,64 * *$ & 0,0020 \\
\hline Cek & $3,4 *$ & 0,0341 & Cek & $1,88^{\mathrm{tn}}$ & 0,1629 \\
\hline Jumlah Anakan Produktif & & & Jumlah Gabah Hampa & & \\
\hline Genotipe uji & $4,01 *$ & 0,0193 & $\begin{array}{l}\text { Genotipe uji } \\
\text { Genotipe }\end{array}$ & $3,53 *$ & 0,0302 \\
\hline Genotipe uji_vs_kontrol & $16,98 * *$ & 0,0008 & uji_vs_kontrol & $7,27 *$ & 0,0159 \\
\hline Cek & 2,5 tn & 0,0836 & Cek & $23,9 * *$ & $<, 0001$ \\
\hline Umur Berbunga & & & Seed Set & & \\
\hline Genotipe uji & $55,28 * *$ & $<, 0001$ & $\begin{array}{l}\text { Genotipe uji } \\
\text { Genotipe }\end{array}$ & $3,36 *$ & 0,0353 \\
\hline Genotipe uji_vs_kontrol & $41,09 * *$ & $<, 0001$ & uji_vs_kontrol & $0,51^{\mathrm{tn}}$ & 0,4852 \\
\hline Cek & $25,24 * *$ & $<, 0001$ & Cek & $17,13^{* *}$ & $<, 0001$ \\
\hline Indeks Warna Daun & & & Bobot 1000 butir & & \\
\hline Genotipe uji & $5,77^{* *}$ & 0,0045 & $\begin{array}{l}\text { Genotipe uji } \\
\text { Genotipe }\end{array}$ & $12,4 * *$ & $<, 0001$ \\
\hline Genotipe uji_vs_kontrol & $14,21 * *$ & 0,0017 & uji_vs_kontrol & $8,75^{* *}$ & 0,0093 \\
\hline Cek & $6,66^{* *}$ & 0,0024 & Cek & $7,93 * *$ & 0,0010 \\
\hline Bobot Brangkasan Basah & & & Bobot gabah per rum & (hasil) & \\
\hline Genotipe uji & $5,08 * *$ & 0,0078 & $\begin{array}{l}\text { Genotipe uji } \\
\text { Genotipe }\end{array}$ & $57,13^{* *}$ & $<, 0001$ \\
\hline Genotipe uji_vs_kontrol & $0,42^{\mathrm{tn}}$ & 0,5250 & uji_vs_kontrol & $17,52 * *$ & 0,0007 \\
\hline Cek & 2 tn & 0,1437 & Cek & $14,65^{* *}$ & $<, 0001$ \\
\hline \multicolumn{6}{|l|}{ Bobot Brangkasan Kering } \\
\hline Genotipe uji & $19,63 * *$ & $<, 0001$ & & & \\
\hline Genotipe uji_vs_kontrol & $0,42^{\text {tn }}$ & 0,5255 & & & \\
\hline Cek & $1,81^{\text {tn }}$ & 0,1764 & & & \\
\hline
\end{tabular}

Keterangan: $^{* *}=$ berbeda sangat nyata pada taraf $1 \%,{ }^{*}=$ berbeda nyata pada taraf $5 \%$, th $=$ tidak berbeda nyata. 


\section{Pendugaan Ragam Genetik Berdasarkan Rancangan Percobaan Augmanted Design}

Pendugaan ragam genetik dianalisis berdasarkan rancangan percobaan Augmented Design. Pendugaan menunjukkan hampir semua karakter memiliki ragam genetik dan fenotip yang berkriteria luas kecuali karakter gabah isi. Keragaman paling luas dimiliki oleh karakter bobot hasil gabah per 5 rumpun (Tabel 5 ).

Tabel 5. Pendugaan ragam genetik galur-galur pada kondisi kekeringan

\begin{tabular}{|c|c|c|c|c|c|c|c|c|c|}
\hline $\begin{array}{l}\text { Karakter } \\
\text { agronomis }\end{array}$ & $\sigma_{\varepsilon}^{2}$ & $\sigma_{G}^{2}$ & $\sigma_{P k}^{2}$ & $\mathrm{~h}_{\text {bs }}^{2}$ & $2 \sigma_{\sigma_{G}^{2}}$ & $2 \sigma_{\sigma_{p}^{2}}$ & $\begin{array}{l}\text { Kriteria } \\
\text { ragam } \\
\text { genetic }\end{array}$ & $\begin{array}{l}\text { Kriteria } \\
\text { ragam } \\
\text { fenotip }\end{array}$ & $\% \mathrm{KGH}$ \\
\hline Tinggi tanaman & 1,28 & 33,97 & 35,26 & 0,964 & 1,28 & 0,96 & Luas & Luas & 9,82 \\
\hline $\begin{array}{l}\text { Jumlah anakan } \\
\text { produktif }\end{array}$ & 0,42 & 0,71 & 1,13 & 0,628 & 0,31 & 0,13 & Luas & Luas & 9,20 \\
\hline Umur berbunga & 0,20 & 6,04 & 6,23 & 0,969 & 0,21 & 0,16 & Luas & Luas & 6,45 \\
\hline $\begin{array}{l}\text { Indeks warna } \\
\text { daun }\end{array}$ & 0,25 & 2,88 & 3,14 & 0,920 & 0,21 & 0,12 & Luas & Luas & 7,34 \\
\hline $\begin{array}{l}\text { Bobot } \\
\text { brangkasan } \\
\text { kering }\end{array}$ & 0,87 & 22,84 & 23,71 & 0,964 & 0,87 & 0,65 & Luas & Luas & 24,38 \\
\hline $\begin{array}{l}\text { \% pengisian } \\
\text { bulir }\end{array}$ & 5,13 & 12,26 & 17,40 & 0,705 & 3,80 & 1,66 & Luas & Luas & 8,52 \\
\hline $\begin{array}{l}\text { Bobot } 1000 \\
\text { butir }\end{array}$ & 0,03 & 2,33 & 2,36 & 0,986 & 0,05 & 0,05 & Luas & Luas & 9,80 \\
\hline Hasil 5 rumpun & 21,3 & 154,96 & 176,24 & 0,880 & 16,65 & 8,72 & Luas & Luas & 13,93 \\
\hline
\end{tabular}

Nilai heritabilitas arti luas menunjukkan bahwa semua karakter berkriteria tinggi. Nilai heritabilitas tertinggi dimiliki oleh karakter bobot hasil per 5 rumpun. Hal ini sangat baik untuk memperoleh pendugaan nilai kemajuan genetik yang tinggi. Terlihat bahwa nilai heritabilitas dapat bernilai negatif pada suatu karakter tertentu. Dalam hal ini, kondisi kekeringan atau suatu kondisi stres diduga dapat membuat nilai heritabilitas menjadi negatif seperti yang terjadi pada karater jumlah gabah isi. Karakter gabah isi biasanya bernilai heritabilitas positif pada kondisi normal seperti contohnya pada hasil penelitian Sutaryo (2014). Pada kasus pendugaan ragam genetik jagung pada kondisi stres kekeringan memperlihat hal yang sama yaitu terdapat beberapa karakter yang nilai heritabilitasnya negatif. Penelitian Azrai et al. (2015) menunjukkan kondisi stress kekeringan membuat nilai heritabilitas panjang tongkol, umur berbunga, dan bobot 1.000 butir bernilai negatif. Seleksi suatu karakter yang diinginkan akan lebih berarti apabila karakter tersebut mudah diwariskan (Wahyuni, 2004). Dalam hal ini, heritabilitas yang berkriteria tinggi merupakan indikator bahwa karakter tersebut mudah untuk diwariskan. Heritabilitas yang mengukur sejauh mana variabilitas sifat kuantitatif diturunkan dapat menunjukkan efektivitas seleksi genotip yang didasarkan pada penampilan fenotip (Saleem et al., 2008).

Seleksi mengharapkan nilai heritabilitas serta variabilitas yang tinggi untuk memperoleh efektivitas kemajuan seleksi yang tinggi. Efektivitas kemajuan seleksi dapat diduga dengan melihat nilai persentase kemajuan genetik harapan (\%KGH). Berdasarkan tabel pendugaan ragam genetik, tidak direkomendasikan seleksi berdasarkan karakter jumlah gabah isi per malai karena nilai heritabilitas 
bernilai negatif serta variabilitasnya yang sempit. Terlihat pada pendugaan kemajuan genetik harapan yang tergolong rendah bahkan bernilai minus. Seleksi pada kondisi kekeringan efektif apabila berdasarkan karakter bobot brangkasan kering. Karakter ini memiliki variabilitas genetik dan fenotip yang luas dengan nilai duga heritabilitas arti luas paling tinggi dibanding karakter lain serta nilai duga kemajuan genetik harapan yang tergolong kriteria tinggi sebesar 24,38\%. Efektif disini dalam arti bahwa peningkatan nilai rata-rata bobot brangkasan kering akan besar namun belum tentu bobot hasil panen atau potensi hasil panen akan besar karena perlu identifikasi lebih lanjut pengaruh tak langsung dari karakter bobot brangkasan kering terhadap hasil (yield).

Berbeda halnya untuk karakter jumlah gabah hampa, nilai KGH tergolong tinggi, namun yang diharapkan untuk karakter ini adalah nilai $\mathrm{KGH}$ yang kecil karena semakin kecil KGH artinya semakin kecil jumlah gabah hampa. Karakter bobot hasil 5 rumpun merupakan karakter yang memiliki $\%$ KGH tertinggi kedua setelah bobot brangkasan kering. Nilai \% $\mathrm{KGH}$ sebesar 13,9\% (berkriteria tinggi). Dengan demikian seleksi langsung berdasarkan karakter bobot hasil 5 rumpun adalah efektif.

Tabel 6. Perbandingan hasil seleksi dengan intensitas seleksi 10 berdasarkan dua karakter bernilai \% KHG tertinggi

\begin{tabular}{cccc}
\hline \multicolumn{2}{c}{ Seleksi berdasarkan $Y$} & \multicolumn{2}{c}{ Seleksi berdasarkan Bobot brangkasan kering } \\
\hline Gen & Hasil per 5 rumpun $(\mathrm{g})$ & Gen & Hasil per 5 rumpun (g) \\
2 & $\mathbf{1 7 7 , 8 0}$ & 5 & $\mathbf{1 7 1 , 2 0}$ \\
18 & $\mathbf{1 7 3 , 1 0}$ & 98 & $\mathbf{1 7 0 , 0 0}$ \\
42 & $\mathbf{1 7 1 , 5 0}$ & 19 & $\mathbf{1 6 9 , 0 0}$ \\
5 & $\mathbf{1 7 1 , 2 0}$ & 87 & 151,30 \\
98 & $\mathbf{1 7 0 , 0 0}$ & 83 & 150,70 \\
19 & 169,00 & 80 & 140,80 \\
60 & 165,00 & 85 & 135,70 \\
21 & 160,30 & 84 & 134,30 \\
39 & 154,60 & 92 & 96,40 \\
35 & 152,70 & 33 & 84,50 \\
$\mu$ & 166,52 & & 140,39 \\
C1 & 111,56 & C1 & 111,56 \\
C2 & 149,42 & C2 & 149,42 \\
C3 & 168,94 & C3 & 168,94 \\
C4 & 91,00 & C4 & 91,00 \\
C5 & 147,46 & C5 & 147,46 \\
\hline
\end{tabular}

Keterangan : $\mathrm{Y}=$ bobot hasil per 5 rumpun, $\mu=$ nilai rata-rata 10 galur terbaik, $\mathrm{C} 1=$ Ciherang, $\mathrm{C} 2=$ Inpari $10, C 3=$ Inpari 13, C4 = Inpari 23, C5 = St. Bagendit

Seleksi berdasarkan bobot brangkasan dari 5 rumpun tergolong seleksi tidak langsung karena karakter agronomi ini merupakan karakter komponen hasil sedangkan seleksi berdasarkan karakter bobot hasil gabah 5 rumpun merupakan 
seleksi langsung karena karakter ini merupakan karakter hasil. Sepuluh galur promising hasil seleksi dengan intensitas seleksi sebesar $10 \%$ berdasarkan dua karakter ini disajikan pada Tabel 6.

\section{SIMPULAN}

1. Kondisi kekeringan menghasilkan keragaan nilai rata-rata galur untuk karakter tinggi tanaman 103,44 cm, jumlah anakan produktif 12 anakan, persentase pengisian bulir bernas hanya mencapai $60,46 \%$, indeks warna daun 39,37 , bobot 1.000 butir rata-rata sekitar 26,34 g dengan bobot hasil gabah per 5 rumpun sekitar 166,34 g setara $3,77 \mathrm{t} \mathrm{ha}^{-1}$.

2. Semua karakter memiliki variabilitas yang luas, nilai heritabilitas tinggi dan persentase $\mathrm{KGH}$ yang tinggi kecuali jumlah bulir bernas per malai.

3. Seleksi berdasarkan karakter bobot hasil 5 rumpun paling efektif dibandingkan karakter lain untuk kondisi stress kekeringan.

4. Galur BP17572c-SBY-1-CRB-2-SKI-1-3PWK-2, ZX115-SKI-0-IND-2-SKI-1-PWK-2, BP30104e, BP17572c-SBY-1-CRB-2-SKI-14-PWK-2, dan BP17554-1C-SBY-1-CRB-8SKI-1-6-PWK-2 adalah galur-galur promising untuk dilanjutkan pada uji daya hasil pendahuluan untuk perakitan varietas padi tadah hujan.

\section{UCAPAN TERIMAKASIH}

Ucapan terimakasih kepada DIPA 2016 Kementerian Pertanian yang telah membiayai penelitian.

\section{DAFTAR PUSTAKA}

Adriani, A., M. Azrai, W. B. Suwarno, S. H. Sutjahjo. 2015. Pendugaan keragaman genetik dan heritabilitas jagung hibrida silang puncak pada perlakuan cekaman kekeringan. Informatika Pertanian, Vol. 24 No.1 : 91- 100 .

Basis Data Deptan. 2017. Luas Panen Tanaman Pangan. http://aplikasi.pertanian.go.id/bdsp/h asil_kom.asp.

BB Padi. 2015. Deskripsi VUB. Badan Litbang Pertanian. Kementerian Pertanian.

Fagi, A.M. 1995. Strategi for Improving Rainfed Lowland Rice Production System in Central Java. In Ingram. K.T. (Ed), Rainfed Lowland Rice: Agricultural Research for High-Risk Environments, Manila: IRRI.

Falconer, D. S. 1989. Introduction to Quantitative Genetiks. Third edition. English Language Book Society Longman, Hongkong. 438 pages.

Federer, W.T. and D. Raghavarao. 1975. On augmented design. Biometrics, Vol. 31, No. 1: 29-35.

Pane, H., A. Wihardjaka, dan A.M. Fagi. 2009. Menggali potensi produksi padi tadah hujan. http://www.litbang.pertanian.go.id/s pecial/padi/bbpadi_2009_itp_07.pdf.

Petersen, R.G. 1994. Agricultural field experiment: Design and analysis. Mareel Dekker Inc. New York.

Prihasto. 2013. Model pertanian ramah lingkungan pada sawah dan lahan sawah tadah hujan. Raker Balai Besar 
Litbang Sumberdaya Lahan Pertanian. Bogor, 3-6 April 2013.

PTTIPB. 2008. Augmented design. https://pttipb.wordpress.com/catego ry/07-pengujian-populasi-generasiawal/74-augmented-design/.

Rohaeni, W.R., U. Susanto, R.H. Wening, dan S.R. Dalimunthe. 2015. Evaluasi Karakter Agronomis Galur-galur Padi Tadah Hujan Generasi Lanjut. Prosiding Seminar Nasional Padi, "Pertanian berkelanjutan mendukung kedaulatan pangan nasional", Medan 3 Desember 2015.

Wahyuni, T. S., R. Setiamihardja, N. Hermiati, dan K. H. Hendroatmodjo. 2004. Variabilitas Genetik, Heritabilitas, dan Hubungan Antara Hasil Umbi dengan Beberapa Karakter Kuantitatif dari 52 Genotipe Ubi Jalar di Kendalpayak Malang. Zuriat, 15(2):109-117.

Wahyunto. 2009. Lahan sawah di indonesia sebagai pendukung ketahanan pangan nasional. Informatika Pertanian, Vol. 18 No. 2: 133-152.

Saleem MY, JI Mirza, and MA Haq. 2008. Heritability, genetic advance, and heterosis in line $x$ tester crosses of Basmati rice. Journal Agricultural Research 46,15-26.

Stansfield, W. D., 1991. Genetika. Alih Bahasa M. Affandi dan L. T. Hardy. Erlangga, Jakarta.

Sutaryo, B. 2014. Parameter genetik sejumlah genotip padi di lahan sawah berpengairan teknis dan tadah hujan. Berita Biologi, 13(1): 23-29. 